\title{
Flood Inundation Mapping Using HEC-RAS Model; The Case of Awash Bello Flood Plain, Upper Awash Basin, Oromiya Regional State,Ethiopia
}

\author{
Wana Namara ${ }^{1}$, Tamene Damisse ${ }^{1}$, and Fayera Tufa ${ }^{1}$ \\ ${ }^{1}$ Jimma University College of Engineering and Technology
}

June 17, 2020

\begin{abstract}
Abstract Flood is the devastating natural events as it causes massive destructive of life, economy and infrastructure. The main objective of this study was flood inundation mapping using HEC-RAS model; the case of Awash Bello flood plain, Upper Awash River basin, Ethiopia. River geometry, annual peak flood, and boundary conditions are the most important input parameters for RAS preprocessing. River geometry such as river center line, left and right bank line, flow path line, and XS Cut line were extracted from DEM of the Awash Bello flood plain with aid of the Arc GIS and HEC-RAS interface called HEC-Geo RAS and exported to HEC-RAS for the completion of RAS preprocessing. Annual peak flood frequency analysis for different recurrence interval (i.e. 2,5,10,25,50, and 100-years) were computed using the calibrated and validated HEC-HMS model based on a 25 years (1990-2015) hydro-meteorological data collected from Ministry of Water Resources Irrigation and Electricity and National Meteorological Agency respectively. The model result depicted the flood extreme value for the respective recurrence interval were 526,610,828.8,1072.8,1263.6, and $1461.3 \mathrm{~m} 3 / \mathrm{s}$ respectively. For more reliability, the HEC-HMS model outputs were compared with the flood extreme value obtained from Log-Pearson type III, General Pareto and Gumbel extreme value distribution function and it was found the HEC-HMS model result for every recurrence interval were higher than the extreme value distribution function outputs. After verifying the acceptability of the HEC-HMS model result, the verified peak flood was inserted into HEC-RAS model and flood inundation mapping for different recurrence interval were executed. The HEC-RAS model outcome indicated that the flood inundation mapping area for 2,5,10,25,50, and 100-year recurrence interval respectively were $71.475,76.630,89.150,100.290,105.160$, and $109.462 \mathrm{~km} 2$. Finally, it was realized that the whole Awash Bello flood plain is under the influence of flood inundation due to the intensive rainfall event. Key Words: Awash Bello, DEM, Flood Frequency Analysis, Flood Inundation Mapping, HEC-HMS, HEC-RAS, HEC-Geo RAS, Arc GIS,
\end{abstract}

This study is focused on the flood inundation mapping of Awash Bello Flood Plain, Upper Awash river basin, Oromiya Regional state, Ethiopia with aid of HEC-RAS model

Key Words: Awash Bello, DEM, Flood Frequency Analysis, Flood Inundation Mapping,

HEC-HMS, HEC-RAS, HEC-Geo RAS, Arc GIS,

Title: Flood Inundation Mapping Using HEC-RAS Model; The Case Awash Bello Flood Plain, Upper Awash Basin, Oromiya Regional State, Ethiopia.

Wana Geyisa Namara ${ }^{a}$, Dr. Ing. Tamene Adugna Damisse (Associate. Prof.) ${ }^{\text {b }}$, and Fayera Gudu Tufa (Assist. Prof.) ${ }^{\mathrm{c}}$

a,b,c Jimma University, Jimma Institute of Technology, Department of Hydrology and Hydraulic Engineering 


\section{Acknowledgments}

Without the financial support from the Ethiopian Road Authority it would not be possible to complete the study. So we, the authors, are grateful to the Ethiopian Road Authority for the financial support.

\section{Hosted file}

Running Head.docx available at https://authorea.com/users/334056/articles/460120-floodinundation-mapping-using-hec-ras-model-the-case-of-awash-bello-flood-plain-upper-awashbasin-oromiya-regional-state-ethiopia

\section{Hosted file}

Key Words.docx available at https://authorea.com/users/334056/articles/460120-floodinundation-mapping-using-hec-ras-model-the-case-of-awash-bello-flood-plain-upper-awashbasin-oromiya-regional-state-ethiopia

\section{Hosted file}

Abstract.docx available at https://authorea.com/users/334056/articles/460120-floodinundation-mapping-using-hec-ras-model-the-case-of-awash-bello-flood-plain-upper-awashbasin-oromiya-regional-state-ethiopia

\section{Hosted file}

FIM main text.docx available at https://authorea.com/users/334056/articles/460120-floodinundation-mapping-using-hec-ras-model-the-case-of-awash-bello-flood-plain-upper-awashbasin-oromiya-regional-state-ethiopia

\section{Hosted file}

Reference.docx available at https://authorea.com/users/334056/articles/460120-floodinundation-mapping-using-hec-ras-model-the-case-of-awash-bello-flood-plain-upper-awashbasin-oromiya-regional-state-ethiopia

\section{Hosted file}

Figure-1.docx available at https://authorea.com/users/334056/articles/460120-floodinundation-mapping-using-hec-ras-model-the-case-of-awash-bello-flood-plain-upper-awashbasin-oromiya-regional-state-ethiopia

\section{Hosted file}

Figure-2.docx available at https://authorea.com/users/334056/articles/460120-floodinundation-mapping-using-hec-ras-model-the-case-of-awash-bello-flood-plain-upper-awashbasin-oromiya-regional-state-ethiopia

\section{Hosted file}

Figure-3.docx available at https://authorea.com/users/334056/articles/460120-floodinundation-mapping-using-hec-ras-model-the-case-of-awash-bello-flood-plain-upper-awashbasin-oromiya-regional-state-ethiopia

\section{Hosted file}

Figure-4.docx available at https://authorea.com/users/334056/articles/460120-floodinundation-mapping-using-hec-ras-model-the-case-of-awash-bello-flood-plain-upper-awashbasin-oromiya-regional-state-ethiopia

\section{Hosted file}


Figure-5.docx available at https://authorea.com/users/334056/articles/460120-floodinundation-mapping-using-hec-ras-model-the-case-of-awash-bello-flood-plain-upper-awashbasin-oromiya-regional-state-ethiopia

\section{Hosted file}

Figure-6.docx available at https://authorea.com/users/334056/articles/460120-floodinundation-mapping-using-hec-ras-model-the-case-of-awash-bello-flood-plain-upper-awashbasin-oromiya-regional-state-ethiopia

\section{Hosted file}

Figure-7.docx available at https://authorea.com/users/334056/articles/460120-floodinundation-mapping-using-hec-ras-model-the-case-of-awash-bello-flood-plain-upper-awashbasin-oromiya-regional-state-ethiopia

\section{Hosted file}

Figure-8.docx available at https://authorea.com/users/334056/articles/460120-floodinundation-mapping-using-hec-ras-model-the-case-of-awash-bello-flood-plain-upper-awashbasin-oromiya-regional-state-ethiopia

\section{Hosted file}

Figure-9.docx available at https://authorea.com/users/334056/articles/460120-floodinundation-mapping-using-hec-ras-model-the-case-of-awash-bello-flood-plain-upper-awashbasin-oromiya-regional-state-ethiopia

\section{Hosted file}

Figure-10.docx available at https://authorea.com/users/334056/articles/460120-floodinundation-mapping-using-hec-ras-model-the-case-of-awash-bello-flood-plain-upper-awashbasin-oromiya-regional-state-ethiopia

\section{Hosted file}

Figure-11.docx available at https://authorea.com/users/334056/articles/460120-floodinundation-mapping-using-hec-ras-model-the-case-of-awash-bello-flood-plain-upper-awashbasin-oromiya-regional-state-ethiopia

\section{Hosted file}

Figure-12.docx available at https://authorea.com/users/334056/articles/460120-floodinundation-mapping-using-hec-ras-model-the-case-of-awash-bello-flood-plain-upper-awashbasin-oromiya-regional-state-ethiopia

\section{Hosted file}

Figure-13.docx available at https://authorea.com/users/334056/articles/460120-floodinundation-mapping-using-hec-ras-model-the-case-of-awash-bello-flood-plain-upper-awashbasin-oromiya-regional-state-ethiopia 